\title{
PELATIHAN BIOENTERPRENEURSHIP BAGI REMAJA PUTUS SEKOLAH DI LOPOSOS DESA SAMBIREJO UNTUK MENINGKATKAN EKONOMI DI SEKTOR INDUSTRI KREATIF
}

\author{
Pebriani Rahmawati $1^{*}$, Irma Nuril Afreza ${ }^{2}$, Mushtofa Lutfil Anshori ${ }^{3}$, \\ Qori Anjani Putri ${ }^{4}$, Restu Lusiana ${ }^{5}$ \\ 1,2Universitas PGRI Madiun, Madiun, Indonesia \\ 1*rahmawati.febriani@gmail.com \\ irmanurilafreza@gmail.com \\ 3mushtofaa@gmail.com \\ 4qorianjani79@gmail.com \\ 5restu.mathedu@unipma.ac.id
}

\begin{abstract}
Abstrak:
Masa pandemi covid-19 menjadi tantangan bagi masyarakat di lingkungan pondok sosial (LIPOSOS) desa Sambirejo. Hal tersebut diarenakan adanya PPKM yang membatasi mereka untuk bekerja untuk memenuhi kebutuhan hidup. Tujuan kegiatan ini adalah untuk memberikan pengetahuan bioenterpreneurship untuk remaja putus sekolah di LIPOSOS desa Sambirejo sebagai upaya membangun ekonomi kreatif di masa pandemic Covid-19. Kegiatan ini menggunakan metode pelaksanaan yang meliputi 3 tahapan diantaranya pensiapan, pelaksanaan, dan evaluasi. Hasil kegiatan tersebut adalah remaja putus sekolah mendapatkan keterampilan baru dalam bidang bioenterpreneurship, mendapatkan keterampilan dalam menciptakan peluang usaha, dan mendapatkan keterampilan dalam pemasaran produk baik secara langsung maupun secara online. Kegiatan tersebut dapat memperbaiki kondisi ekonomi masyarakat LIPOSOS dalam sector industry kreatif, dan dalam jangka Panjang diharapkan mampu memperbaiki kesejahteraan masyarakat di LIPOSOS desa Sambirejo.
\end{abstract}

Kata Kunci: Bioenterpreneurship, Remaja Putus Sekolah, LIPOSOS, Ekonomi, Industri Kreatif.

\section{Pendahuluan}

Pemberdayaan masyarakat bertujuan untuk meningkatkan taraf hidup masyarakat agar lebih mandiri dan sejahtera dalam kehidupannya. Salah satu langkah nyata pemerintah dalam upaya meningkatkan kesejahteraan masyarakat adalah melalui penerbitan kebijakan pemerintah yang tertuang pada program Nawacita yang berisi 9 aspek yang menjadi prioritas pembangunan Presiden Joko Widodo selama menjadi Presiden Republik Indonesia. Terdapat 2 Program Nawacita yang pro pada program pengentasan kemiskinan, yaitu membangun Indonesia dari pinggiran dengan memperkuat daerah-daerah dan desa dalam kerangka negara kesatuan, dan meningkatkan kualitas hidup manusia Indonesia melalui program Indonesia 
Pintar dengan wajib belajar 12 tahun bebas pungutan dan program Indonesia Sehat untuk peningkatan layanan kesehatan masyarakat. Serta Indonesia Kerja dan mendorong program kepemilikan tanah seluas sembilan juta hektar.

Namun di Negara berkembang seperti di Indonesia masih banyak permasalahanpermasalahan yang dihadapi, salah satunya adalah tingkat kemiskinan dan remaja putus sekolah yang masih relatif tinggi. Berdasarkan data Badan Statistik pada Maret 2016 di Indonesia jumlah penduduk miskin atau penduduk dibawah garis kemiskinan mencapai 28,01 juta jiwa atau sebesar 10,86 persen dari total jumlah penduduk Indonesia. Kemiskinan dipicu karena masih banyaknya masyarakat yang memiliki tingkat pendidikan yang masih rendah dan juga lapangan pekerjaan yang masih relatif terbatas. Kemiskinan juga telah membuat jutaan generasi muda tidak bisa mengenyam pendidikan tinggi. Hal tersebut juga terjadi di kabupaten Madiun karena kebdasarkan data dari madiunkab.bps.go.id (23/01/2019) prosentase garis kemiskinan dan penduduk miskin di kabupaten Madiun pada tahun 2012-2017 adalah 12,61\%. Berdasarkan hal tersebut pemberdayaan masyarakat harus terus dilakukan, khususnya di lingkungan pondok sosial (LIPOSOS).
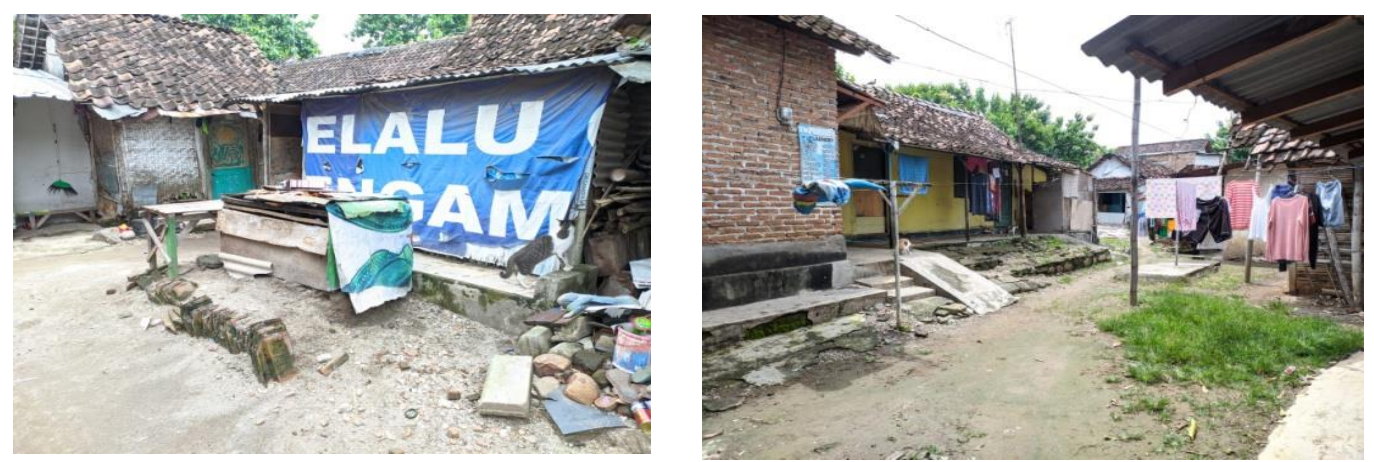

Gambar 1. Kondisi Lingkungan Pondok Sosial

Gambar tersebut mendeskripsikan kondisi LIPOSOS yang terletak di RT. 27 dan RT. 26 RW.01 Desa Sambirejo, Kecamatan Jiwan, Kabupaten Madiun, Jawa Timur. Sebagian besar masyarakat yang berada di lingkungan LIPOSOS Desa Sambirejo merupakan masyarakat yang memiliki tingkat perekonomian menengah ke bawah. Mereka juga harus bersiap pindah karena bangungan yang mereka tempati adalah milik pemerintah kabupaten Madiun. Dari sini timbul kekhawatiran mereka akan menjadi gepeng kembali jika pindah dari LIPOSOS. Ironisnya remaja dilingkungan tersebut memiliki minat yang rendah untuk menempuh dan melanjutkan pendidikan, baik di tingkat SMP maupun SMA, dikarenakan latar belakang orang tua yang kurang memahami pentingnya pendidikan dan keterbatasan ekonomi. Untuk memenuhi 
kebutuhan hidup tidak jarang mereka meminta-minta di jalan, mengamen, memulung, serta ada beberapa yang menjadi menjadi buruh serabutan, dan ironisnya remaja putus sekolah juga dilibatkan dalam kegiatan tersebut. Hal tersebut menjadi permasalahan besar yang harus di selesaikan agar remaja putus sekolah tetap dapat meningkatkan taraf hidup mereka di masa depan.

Sudah ada beberapa upaya dilakukan untuk memberdayakan masyarakat di LIPOSOS desa Sambirejo, diantaranya memberikan pelatihan kerajinan flannel untuk anak putus sekolah sebagai upaya menciptakan home industry kreatif (Arrosida \& Echsony, 2018), namun saat ini sudah tidak lagi berjalan. Hal tersebut dikarenakan kurangnya pemahaman masyarakat dalam hal inovasi produk dan pemasaran. Di tambah lagi saat ini dunia, khususnya Indonesia tengah dilanda pandemic Covid 19 yang mengharuskan kita semua untuk meminimalir kegiatan yang menimbulkan kerumunan (Wajdi et al., 2020). Hal tersebut dilakukan sebagai upaya untuk memutus rantai penyebaran virus Covid-19 (Saleh \& Mujahiddin, 2020).

Selama masa pandemi, mengharuskan kita, tak terkecuali anak-remaja putus sekolah untuk tetap berada di rumah, hal ini tentu akan menimbulkan rasa bosan dan stress pada remaja putus sekolah yang mengakibatkan interaksi remaja putus sekolah dengan gaget semakin meningkat. Berdasarkan (Maria \& Novianti, 2020) efek penggunaan gadget pada masa pandemi Covid-19 terhadap perilaku anak yang paling dominan berada pada indikator compulsion. Oleh karena itu, semua pihak, khususnya orang tua harus dapat memenuhi kebutuhan psikososial anak. Hal ini bisa mengurangi dampak psikososial pada anak, seperti stress yang dapat mempengaruhi perilaku, mental dan aktivitas psikososial (Rohayani, 2020).

Berdasarkan permasalahan di atas akan diadakan pelatihan Bioentrepreneurship pada remaja putus sekolah di LIPOSOS desa Sambirejo sebagai upaya peningkatan ekonomi kreatif di masa pandemi Covid-19. Pelaksanaan kegiatan dilakukan dengan mengkombinasi metode daring dan luring, dengan tetap mematuhi protokol kesehatan yang ada. Kegiatan tersebut diharapkan mampu meningkatkan ekonomi dan kesejahteraan masyarakat di lingkungan LIPOSOS desa Sambirejo, khususnya di sektor industri kreatif, sehingga mereka dapat memiliki kehidupan yang lebih baik di masa mendatang.

\section{Metode Pelaksanaan}

Kegiatan pelatihan dilakukan di LIPOSOS desa Sambirejo kecamatan Jiwan kabupaten Madiun. Pelaksanaan kegiatan dimulai bulan Juni sampai Agustus. Adapun tahapan pelaksanaan program meliputi tahap persiapan, tahap pelaksanaan, dan tahap evaluasi. 
1. Tahapan persiapan program meliputi koordinasi, administrasi, penyusunan pedoman, serta persiapan tempat, alat dan bahan.

2. Tahapan pelaksanaan meliputi sosialisasi, pelatihan, dan pendampingan.

3. Tahapan evaluasi meliputi evaluasi dan perencanaan keberlanjutan kegiatan.

\section{Hasil dan Pembahasan}

\section{Tahap Persiapan}

Langkah pertama pada tahap persiapan dalam program ini adalah Koordinasi persiapan pelaksanaan program secara daring yang diikuti oleh Tim PKM-PM dan perwakilan dari Lingkungan Pondok Sosial. Sosialisasi dilakukan untuk membahas tentang uraian program dan rencana jadwal pelaksanaan serta perubahan metode karena pandemi COVID 19. Adapun respon dari pihak-pihak tersebut sangat baik dan mendukung adanya program yang diharapkan juga dapat berkembang dan diterapkan oleh masyarakat lain serta terlaksana secara berkelanjutan. Ketua paguyuban Lingkungan Pondok Sosial sangat berharap jika program ini dapat berjalan walaupun di masa pandemi COVID 19. Bapak Sunaryo selaku Ketua Paguyuban Lingkungan Pondok Sosial menyampaikan dukungan penuh terhadap program ini. Tim PKM-PM juga menyampaikan bahwa nantinya dilaksanakan sosialisasi dan penyampaian motivasi yang dilakukan secara daring kemudian adanya pelaksanaan pelatihan dan pendampingan program secara luring dan tetap menggunakan protokol kesehatan. Kegiatan selanjutnya yaitu pemasaran produk, diharapkan remaja putus sekolah mampu untuk memasarkan produk yang telah mereka buat baik secara langsung ataupun menggunakan media sosial.

Selain koordinasi dengan pihak terkait, pada tahap persiapan juga dilakukan Penyusunan Modul dan e-Modul dengan judul "Peluang Usaha Kreatif melalui Bioentrepreneurship" oleh tim PKM-PM. Terdapat 2 modul yang isinya sama yaitu modul dan e-modul atau elektronik modul. Dalam hal ini, modul dan e-modul digunakan sebagai acuan dalam mendampingi remaja putus sekolah tentang bioentrepreneurship dan pembuatan kokedama dan kokepot. Emodul berisi langkah-langkah dalam menerapkan sektor unggulan serta cara perawatan berupa teks yang dibuat oleh Tim PKM-PM.

Persiapan alat dan bahan juga dilakukan pada tahap ini. Hasilnya seluruh kegiatan berjalan dengan lancar. Alat serta bahan yang sudah tersedia, diklompokkan dan dibungkus sesuai dengan kebutuhan, yang bertujuan untuk memudahkan pelaksanaan pelatihan dan pendampingan remaja putus sekolah. Dalam pelaksanaan kegiatan mendapatkan respon yang 
sangat baik disampaikan oleh remaja putus sekolah, terbukti banyak yang ingin dan antusian mengikut pelatihan bioentrepreneurship. Selain itu, kami juga memberikan arahan dengan memanfaatkan salah satu ruangan di Lingkungan Pondok Sosial sebagai pusat atau basecamp.

Program ini diharapkan dapat berjalan dengan maksimal sehingga diperlukan banyak dukungan dari stakeholder sehingga nantinya dapat bersama-sama mendukung terciptanya peluang bioenterpreneurship dengan pembuatan kokedama dan kokepot untuk remaja putus sekolah. Adapun stakeholder yang bekerja sama dengan program ini antara lain: Pemerintah Desa Sambirejo, Pemerintah Kecamatan Jiwan, Dinas Sosial Kabupaten Madiun, Radio Republik Indonesia (RRI), dan Omah Santri.

\section{Tahap Pelaksanaan}

Pelaksanaan kegiatan dilakukan dalam 5 kali pertemuan dengan metode daring untuk sosialisasi kegiatan kepada peserta, dan luring saat pelaksanaan pelatihan dan pendampingan. Pelaksanaan kegiatan pelatihan diikuti oleh remaja putus sekolah di Lingkungan Pondok Sosial yang berjumlah sekitar 15 orang dan Tim PKM-PM. Dalam sosialisasi awal membahas tentang pengenalan program, jadwal kegiatan, pengertian bioentrepreneurship dan kokedama dan kokepot. Dalam kegiatan awal tersebut respon remaja putus sekolah di Lingkungan Pondok Sosial sangat baik. Mereka mendukung sepenuhnya program ini, hal tersebut dibuktikan dari banyaknya pertanyaan dan keingintahuan mereka saat sosialisai. Kegiatan selanjutnya yaitu pelaksanaan pelatihan yang didampingi Tim PKMPM.

Pelatihan dilaksanakan secara luring dan tetap mematuhi protokol kesehatan. Kegiatan ini diikuti oleh 15 peserta. Adapun hasil yang telah dicapai adalah remaja putus sekolah mampu membuat kodedama dan kokepot serta mampu melakukan perawatan secara maksimal. Berikut gambaran kegiatan pelatihan yang dilakukan Bersama dengan remaja putus sekolah di LIPOSOS desa Sambirejo.

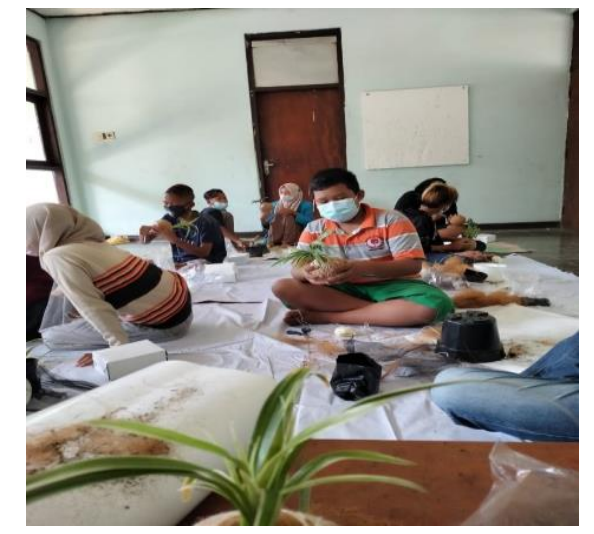

Gambar 2. Pelaksanaan Pelatihan Bioenterpreunership 
Program selanjutnya adalah pendampingan program yang masih dilaksanakan secara luring dan didampingi oleh PKM-PM. Sebelum pelaksanaan kegiatan remaja putus sekolah diwajibkan untuk memakai masker dan menggunakan handsanitizer sebelum memasuki ruangan. Hasil yang telah tercapai yaitu remaja putus sekolah di lingkungan pondok sosial mampu untuk membuat kokedama dan kokepot secara mandiri. Serta remaja putus sekolah belajar memasarkan produk mereka melalui offline dan online dengan menggunakan media sosial.
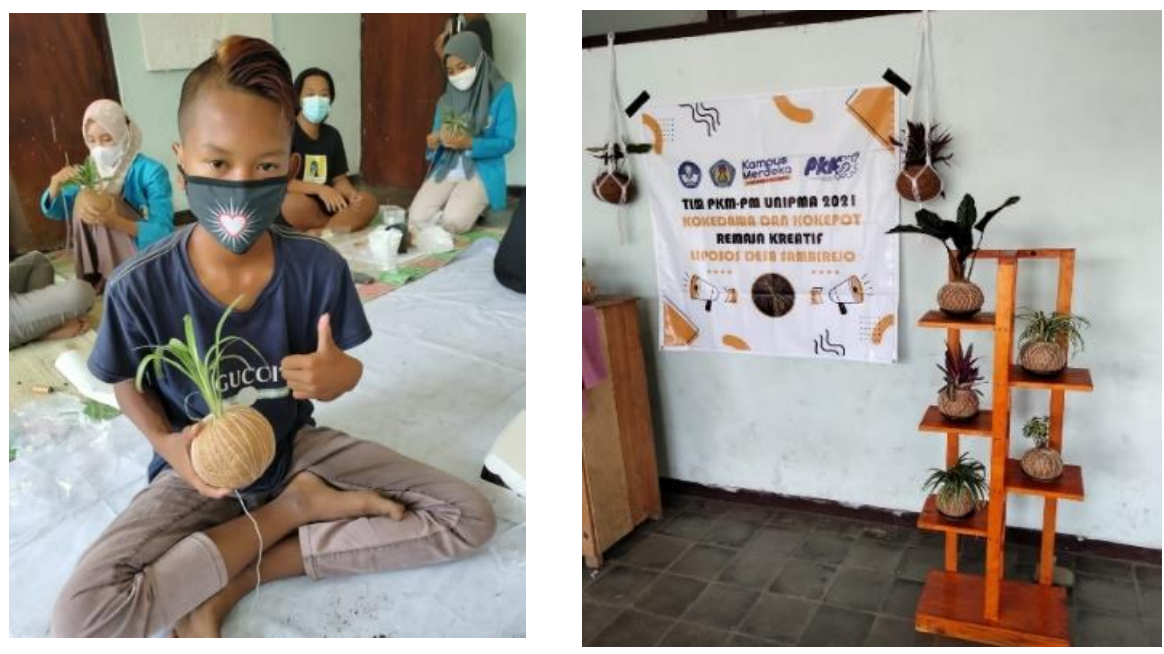

Gambar 3. Produk Kreatif yang Dihasilkan

Hasil dari pelatihan bioenterpreneurship yaitu remaja putus sekolah di LIPOSOS merasa senang dan mampu membuat karya kreatif berupa kokedama, kokepot dan rak kayu, serta hiasan tali untuk kokedama sesuai dengan pelatihan yang telah diberikan saat sosialisasi. Hal tersebut sejalan dengan (Irvan et al., 2020) yang menyatakan bahwa pelaksanaan pelatihan berbasis karya kreatif mendapatkan respon positif dari masyarakat, output pelatihan adalah pengetahuan, wawasan, dan kreativitas masyarakat meningkat.

Setelah produk jadi, dilakukan pelatihan dalam hal pemasaran produk, baik secara langsung maupun menggunakan media sosial. Proses pendampingan terus dilakukan supaya kegiatan dapat berlanjut dan dapat mencapai tujuan yang diharapkan.

\section{Tahap Evaluasi}

Evaluasi dilakukan oleh Tim PKM-PM dengan melihat hasil laporan monitoring yang dilakukan oleh Remaja Kreatif. Berdasarkan pelaksanaan kegiatan pengabdian yang telah dilakukan selama 2 bulan dengan melihat indikator keberhasilan jangka pendek. Potensi hasil 
yang diperoleh dari hasil pelaksanaan kegiatan pengabdian ini dapat dilihat pada uraian berikut: 1) Ruang Lingkup Ekonomi

Remaja putus sekolah di Liposos bisa mengikuti pelatihan ini sehingga penerapan sektor industri kreatif bisa berjalan secara berkelanjutan dan pastinya akan berdampak pada peningkatan ekonomi remaja liposos. Remajanya tidak perlu lagi mengamen untuk mencari biaya kehidupan sehari-hari.

2) Ruang Lingkup Teknologi

Dalam pelaksanaan program pelatihan ini dilengkapi dengan e-modul yang bisa di akses melalui gawai. Dan dalam pelatihan pemasaran produk bisa memanfaatkan sosial media.

3) Ruang Lingkup Sosial

Selain melaksanakan program pelatihan bioentrepreneurship, kami juga mendirikan sebuah gerakan sosial yaitu Remaja Kreatif. Bertujuan untuk mengajak dan memotivasi remaja putus sekolah. Kami juga mempunyai agenda berkelanjutan yaitu mendukung remaja putus sekolah untuk bergerak aktif memanfaatkan peluang di bidang bioentrepreneurship.

4) Ruang Lingkup Artikel Ilmiah

Pelaksanaan program juga dalam publikasi jurnal sebagai pengabdian masyarakat. Hasil publikasi jurnal nantinya dapat menjadi rujukan atau referensi peneliti lain atau pengabdian masyarakat yang sejenis.

\section{Kesimpulan}

Kesimpulan dari Pengabdian kepada Masyarakat ini antara lain masyarakat dan remaja putus sekolah di Liposos mampu mendapatkan peningkatan pendapatan melalui sektor indsutri kreatif. Terwujudnya bioentrepreneurship secara mandiri. Terjalin hubungan sinergis antara tim PKM-PM, masyarakat dan remaja putus sekolah dalam mengembangkan produk kokedama dan kokepot. Saran yang dapat diberikan pada penelitian ataupun pengabdian kepada masyarakat selanjutnya adalah diharapkan agar penelitian ataupun pengabdian kepada masyarakat selanjutnya dapat dilaksanakan pada lingkup yang lebih luas terhadap remaja putus sekolah di kota/kabupaten Madiun.

\section{UcapanTerima Kasih}

Ucapan terimakasih kami sampaikan kepada kemenristekdikti yang telah memberikan kesempatan dan dukungan baik kepada kami berupa pendanaan program kreativitas mahasiswa, Universitas PGRI Madiun, dosen pendamping PKM-PM dan rekan-rekan tim 
PKM-PM serta remaja putus sekolah di Liposos Kabupaten Madiun yang telah berkontribusi dan memberikan semangat kepada tim PKM-PM sehingga bisa menyelesaikan kegiatan pengabdian kepada masyarakat dan memberikan manfaat bagi masyarakat khususnya remaja putus sekolah dapat meningkatkan kemampuan remaja dalam bioentrepreneurship dan meningkatkan kesejahteraan melalui sektor industri kreatif.

\section{Referensi}

Arrosida, H., \& Echsony, M. E. (2018). Pemberdayaan Anak Putus Sekolah Melalui Pelatihan Pembuatan Kerajinan Flanel. DIKEMAS (Jurnal Pengabdian Kepada Masyarakat), 1(1), 26-31. https://doi.org/10.32486/jd.v1i1.169

Irvan, M., Ilmi, A. M., Choliliyah, I., Nada, R. F., Isnaini, S. L., \& Khorinah, S. A. (2020). Pembuatan Batik Shibori Untuk Meningkatkan Kreativitas Masyarakat Pada Masa Pandemi. Jurnal Graha Pengabdian, 2(3), 223-232.

Maria, I., \& Novianti, R. (2020). Efek Penggunaan Gadget pada Masa Pandemi Covid-19 terhadap Perilaku Anak ( The Effects of Using Gadgets during the Covid-19 Pandemic on Children's Behaviour ). Atfaluna: Journal of Islamic Early Childhood Education, $3(2), 74-81$.

Rohayani, F. (2020). Menjawab Problematika Yang Dihadapi Anak Usia Dini di Masa. Qawwam: Journal For Gender Mainstreaming, 14(1), 29-50. https://doi.org/10.20414/Qawwam.v14i1.2310

Saleh, A., \& Mujahiddin, M. (2020). Challenges and Opportunities for Community Empowerment Practices in Indonesia during the Covid-19 Pandemic through Strengthening the Role of Higher Education. Budapest International Research and Critics Institute (BIRCI-Journal): Humanities and Social Sciences, 3(2), 1105-1113. https://doi.org/10.33258/birci.v3i2.946

Wajdi, M. B. N., Iwan Kuswandi, Umar Al Faruq, Zulhijra, Z., Khairudin, K., \& Khoiriyah, K. (2020). Education Policy Overcome Coronavirus, A Study of Indonesians. EDUTEC: Journal of Education And Technology, 3(2), 96-106. https://doi.org/10.29062/edu.v3i2.42 